DOI: 10.15643/libartrus-2014.5.4

\title{
Notes From the Dead House: An Exercise in Spatial Reading, or Three Crowd Scenes
}

\author{
(C) C. Apollonio
}

Duke University

500 North Duke St., 27701 Durham, NC, USA.

Phone: +1 (919) 6603140 .

Email: flath@duke.edu

\begin{abstract}
The article offers an analysis of the workings of Dostoevsky's paradoxical poetics of space in three scenes of Notes from the Dead House. In spite of the fact that freedom in its direct meaning is accessible only outside the walls of the prison, and that in our social world it is accessible only to a few, inside the prison freedom can be acquired by everyone, and can be found within every individual The bathhouse scene, as is often noted by critics, offers a picture of hell However, the bathhouse, like the church where the prisoners celebrate Easter, is located in the town, not inside the prison. Parallels are analyzed between these two scenes and the theater scene, which serves as the culmination of Part I. The theatrical performance takes place in the barracks where the prisoners live. The curtain is described in terms that suggest an iconostasis; details of the performance suggest a church service. After the theater, the inhabitants of the fortress experience a deep feeling of calm and blessedness, which they do not experience in any other space: "Everyone was somehow unusually satisfied, even as though happy, and they fell asleep not as at all other times, but almost with a calm spirit". In this way, Notes from the Dead House gives a new vision of freedom at the very center of the prison. The article cites work by Bakhtin, Emerson, Jackson and others.
\end{abstract}

Keywords: Feodor Dostoevsky, Notes from the Dead House, chronotope, theatrical performance, iconostasis, church service, prison freedom.

There is nothing more deceptive than an obvious fact. - Sherlock Holmes

[quoted in The New Yorker, 12/13/04, p. 62]

The visible realm should be likened to the prison dwelling, and the light of the fire inside it to the power of the sun. And if you interpret the upward journey and the study of things above as the upward journey of the soul to the intelligible realm, you'll grasp what I hope to convey... In the knowable realm, the form of the good is the last thing to be seen, and it is reached only with difficulty. Once one has seen it, however, one must conclude that it is the cause of all that is correct and beautiful in anything, that it produces both light and its source in the visible realm, and that in the intelligible realm it controls and provides truth and understanding, so that anyone who is to act sensibly in private or public must see it. (Plato, Republic, 517, b-c)

...уже в остроге, на свободе... Преступление и наказание. Эпилог [4, vol. 6, p. 417]

Notes from the Dead House presents the ultimate Dostoevskian paradox: a memoir-novel, a delusive fictional shell for the presentation of the author's own observations and true-to-life memories (In spite of the fictional frame, critics universally recognize the strongly autobiographical nature of Notes). Dostoevsky's great theme of the resurrection of the fallen man begins here. Here he embeds 
the secret of freedom and new life, at the very center of the most un-free place on earth: a hardlabor camp in the geographical center of the most politically constricted country in the midnineteenth-century European world - Nikolaevan Russia. Paradox dominates. This is a place where one can spend ten years in constant forced communal living ("вынужденное общее сожительство" [4, vol. 4, p. 22]) and yet feel constantly alone; where the hospital is a place to go when one is NOT ill; where the bathhouse is the most filthy place of all; where the most terrifying criminal behaves like an affectionate lapdog; and where the air is so stifling that smoking cigarettes is a way of getting fresh air. Letter to his brother Michael: "It was impossible not to smoke tobacco, for one could suffocate in such a stuffy atmosphere" ("не курить табаку тоже нельзя было, ибо можно было задохнуться в такой духоте", 30 January-22 February 1854) [4, vol. 281, p. 170]. Here the lowest dregs of human society - murderers, perverts, bandits, violent criminals, psychopaths and sociopaths - hold all the power, and the educated, refined members of the nobility are excluded, disenfranchised, alienated. Here is a Dead House teeming with passion and with life. It appears to be an alien world, fictional, distant from our lives. But is it that different from the free world, the "real world", - the world we inhabit? Are we merely voyeurs here, or is this story somehow about and for us? And if it is not our world, then are we excluded from the book's message of reconciliation and peace? Here, after all, is where Dostoevsky offers his parable of resurrection - not from the Dead House, or outside it, but within, at its very heart.

Unlike Dostoevsky's purely fictional works, which feature a strong story line, Notes from the Dead House offers only the most rudimentary plot construction. It presents the experiences and observations of its autobiographical narrator, wife-murderer Aleksander Petrovich Gorianchikov, over the course of a single year in a Siberian hard-labor prison. A sense of cyclical time dominates; the succession of the seasons and the religious rituals that celebrate them provide a clearly circular temporal structure for the work. The experiences of this year are presented as typical of life in prison in general, and at the end, the remaining nine years of the narrator's ten-year sentence are compressed and reduced to little or no narrative significance. The effect is a nullification of linearity in the temporal dimension of narration. As he anticipates the end of his sentence, for example, Gorinachikov writes: "I had entered the prison in the winter and so it was in winter that I was to be released, on the same date of the month on which I had arrived". ("Поступил я в острог зимой и потому зимой же должен был выйти на волю, в то самое число месяца, в которое прибыл" [4, vol. 4, p. 230]). It is most likely the relatively weak plot construction of Notes that has kept it from the front rank of Dostoevsky's works in the reading public, in spite of the enthusiasm of readers no less authoritative than Lev Tolstoy, who included it in his "top five" (In Chapter XVI of What is Art, Tolstoy singles out Notes from the Dead House when including Dostoevsky with Schiller, Victor Hugo, Dickens, and George Eliot as the writers whose works exemplify the highest religious art [14]), and Nietzsche [8, pp. 148-149]. Recognizing this relatively a-temporal nature of Notes from the Dead House, I would like to propose a "spatially" oriented reading of the work. What is the nature of the physical world of the Dead House - its stage, its scenery, and its boundaries, - where does Dostoevsky situate the key scenes of his account, and what role do these artistic decisions play in communicating his message about freedom and resurrection?

In Problems of Dostoevsky's Poetics, Mikhail Bakhtin identifies the importance of threshold, borderline space - doorways, crossroads, embankments, etc. - as the locus of significant action in Dostoevsky's novels. Thresholds, of course, do not represent a random artistic choice; they are integral to the author's message: "Dostoevsky always represents a person on the threshold of a final deci- 
sion, at a moment of crisis, at an unfinalizable - and unpredeterminable - turning point for his soul" [3, p. 61]. Notes from the Dead House represents an anomaly in this characteristic Dostoevskian pattern. Here the action - if we can call it that - necessarily takes place not on, but within strict boundaries - the prison walls. Here, unlike in the great novels, characters are shown after they have passed over that moment of crisis and decision-making. In order to understand the full depth of Dostoevsky's message, then, the reader must realize that the Dead House represents a fundamentally different chronotope (Chronotope ("literally, 'time-space'”): "the intrinsic connectedness of temporal and spatial relationships that are artistically expressed in literature") [2, p. 84], one that is maximally spatial. In his examination of boundary genres and utopian literature, Gary Saul Morson suggests that Dostoevsky's interest in semi-fictional genres--sketches, feuilletons, and certain kinds of fictionalized journalism (culminating, of course in his Diary of a Writer of the 1870s) - is related to his deep suspicion of the truth value of "realistic art" [12, p. 15]. In a purely Dostoevskian paradox, Notes from the Dead House, itself semi-fictional, "borderline", and "realistic" in nature, locates the significant action in locations maximally distant from borders, at the center of its delineated space.

The space of the Dead House can be taken as representative of our own visible world, in miniature. Our world is a prison, and we - ostensibly free - readers are prisoners here within a greater cosmos that we do not fully understand. Our world, by comparison with what is beyond, is "dead", and that world represents the promise of life (what Dostoevsky soon (in Notes from Underground) will call, tautologically, "alive life" [живая жизнь]. (For some fascinating implications, see [11, pp. 141-198]. For more on "alive life", see [7, pp. 510-529]). At times we are granted a vision, a sense of oneness with that world. Interestingly, in Notes from the Dead House, Dostoevsky seems suggest that these moments of transcendence come not through sacred, religious ritual, but through the medium of secular art, specifically, through the communal experience of theatrical performance. Here the borders between prisoner and free person, between actor and spectator, and between art and "real life" melt away, and the readers are given the chance to share in the prisoners' experience of catharsis.

Any exclusive community divides people into mutually exclusive categories by location: inside and outside. In the case of a prison, of course, these categories are "free" and "un-free". The challenge to the reader is to negotiate our way across the threshold of the text into its inner, ostensibly unfree, space. The barrier of the border is particularly forbidding to the critic, whose task entails detachment, observation, and analysis from outside. Master critic Frank Kermode provides a helpful approach to the problem. In The Genesis of Secrecy, an interpretation of the Gospel of Mark, he divides readers of sacred texts into outsiders and insiders. Outsiders analyze the body of the text; insiders come to the text with trust and faith in the truth of its message:

"Interpreters usually belong to an institution, such as a guild as heralds, toastmasters, thieves, and merchants have been known to form; and as members they enjoy certain privileges and suffer certain constraints. Perhaps the most important of these are the right to affirm, and the obligation to accept, the superiority of latent over manifest sense" [10, p. 2].

The true meaning is a secret life force at the heart of the text that can never be exhausted by any single reader, and that takes on new life with each new generation. It is this attitude toward a text that separates the hermeneutic reader (us gathered here) from the Deconstructionist. The insider believes in and contributes to the holistic, though ineffable, significance within; the Deconstructionist destroys the whole for the sake of the parts - and for Deconstructionist's own, not always overt, purposes. The insider grasps the essence; the outsider sees only the exterior crust. The process of coming to appreciate the inner truth in spite of all appearance is Dostoevsky's focus in his great fic- 
tional works, and it is a process he himself underwent during his years in prison. As he writes his brother Mikhail upon his release from prison:

"People are people everywhere. Even in hard-labor prison, in four years I was able to discern people among the bandits. Can you believe me? There are profound, strong, beautiful characters there, and how delightful it was to discover gold under the coarse crust".

“Люди везде люди. И в каторге между разбойниками я, в четыре года, отличил наконец людей. Поверишь ли: есть характеры глубокие, сильные, прекрасные, и как весело было под грубой корой отыскать золото" (Му emphasis throughout. - С.A. [4, t. 28, p. 172]).

The earnest, well-meaning outsider reads Dostoevsky's Notes to learn about tsarist prisons, or about the author's life or psychology, or about the sociology of the Russian criminal underclass. Such readers may hope to use the knowledge they gain from their reading of the text to improve the state of affairs in their world. By learning about history they hope to avoid repeating the mistakes of the past. Fortunately, though, remaining safely outside the dead house, they experience no challenge to their innocence; the horrors of the prison remain fundamentally separate, irrelevant to their immediate experience. In this paradigm for reading, the text and its author are fragmented, and only the critic remains intact. But to the insider, Dostoevsky's book speaks directly. Dostoevsky's choice to write his memoir in the form of a first-person quasi-fictional narration serves as an invitation to the reader to enter the world of his perception, to see the prison from inside, and to accept it as his or her own world. From this perspective, the external details of the prisoners' lives serve only to confirm our identity with author and prisoner alike, and to reinforce the communal nature of the experience of reading. Penetrating beyond the deceptive, divisive exterior, we discover our human commonalities: I am not in prison, but I too am a prisoner. I share my plight with these - my - people.

No interpretation of Notes from the Dead House is possible without building on the work of Robert Louis Jackson, who devoted four seminal chapters to the work in his The Art of Dostoevsky. My analysis is necessarily a tribute not only to these chapters, but to Jackson's powerful body of Dostoevsky criticism as a whole. In "The Narrator in House of the Dead", Jackson illuminates the counterpoint between the narrator's plot and that of the "broadly ideological plane of action" [9, p. 36]. Gorianchikov "gains freedom only to die a short while later a lonely and broken man. This tragic denouement is of course the direct consequence of the power of the dead house". Nevertheless, on the spiritual level, this pattern is reversed, and the overall message of Notes from the Dead House is the "symbolic redemption of the Russian people" [9, p. 36]. Dostoevsky has moved "from the egoism of suffering, with its limited perspective, to the altruism of artistic vision" [9, p. 52]. As is appropriate for an autobiographical work, then, Notes tells the story of the maturation of an artist (The importance of Dante's Inferno in Dostoevsky's Notes, which is also addressed by Jackson, allows us to see the plot as a katabatic journey, in which a protagonist descends to hell and returns with greater knowledge. Michael Finke explores this pattern in another great Russian writer's journey to Siberia in "The Hero's Descent to the Underworld in Chekhov" [6, pp. 67-80]). Here I should clarify the difference in my approach to the question of "vision" and Jackson's. Jackson focuses on the path of the narrator (and Dostoevsky) from ignorance to deeper knowledge; the prison experience teaches the narrator-author how to see his fellow prisoners as human beings (particularly, as Russians); thence he finds a voice and the ability to write about their shared experience. In my reading, vision comes as a form of grace. Prisoner and reader alike open themselves to revelation. Dostoevsky situates them, as we shall see, in symbolic (disguised, not overt) religious space and instills them with a reverent receptivity to grace, and they (and we) are given the gift of understanding. 
Here again, the message is bound up in paradox. Institutions of religion and human justice prove irrevelant. All generally accepted hierarchies - personal, physical, social, political - are unexpectedly turned on their head, and lowest are raised high. "For whosoever exalteth himself shall be abased; and he that humbleth himself shall be exalted" Luke 14:11 (KJV). The secular reader may prefer Bakhtin's notion of carnival as a reference point ([1]. Also see [5, pp. 89-96]).

The spatial metaphor is central in Notes from the Dead House: the prison is opposed to the world outside. We look out through the eyes of Dostoevsky's narrator, the fictional wife-murderer Gorianchikov. For him the dead house is prison. For us, the walls of the prison come to represent the layered shells of the material world that confine - and protect - our souls (the gold inside the coarse crust) from the world outside. Here the two-dimensionality of fiction borders on the threedimensionality of our world. In its turn, our material environment opens out into a world that makes itself known to us only in indirect ways, through flashes of insight, dreams, and artistic forms of communication. Full understanding is impossible. It will yield its secrets only indirectly, through metaphor. The free reader of Notes and the unfree fictional prisoner, then, - like the prisoners in Plato's cave - both inhabit unfree space, and, through their experience of art, they will both discover a greater freedom.

The opposition between free and confined space is established at the very beginning of the book. Contrary to the expectations of the voyeuristic reader, Siberia - the vast space of prison and exile - is a promised land:

"Not only from the careerist's point of view, but from many others as well, one can thrive in Siberia. The climate is superb, and a large number of remarkably prosperous and hospitable merchants live there. There are numerous extremely well-off non-Russian inhabitants, the girls blossom like roses and are moral to the extreme. Wildlife flies around the streets of the town and bumps right into the hunter. An unnatural amount of champagne is consumed. The caviar is marvelous. The harvest is extraordinarily rich. In general a blessed land. All you have to do is take advantage of it".

“Не только с служебной, но даже со многих точек зрения в Сибири можно блаженствовать. Климат превосходный; есть много замечательно богатых и хлебосольных купцов. Много чрезвычайно достаточных инородцев. Барышни цветут розами и нравственны до последней крайности. Дичь летает по улицам и сама натыкается на охотника. Шампанское выпивается неестественно много. Икра удивительная. Урожай бывает в иных местах сампятнадцать... Вообше земля благословенная. Надо только уметь ее пользоваться" (Му emphasis throughout. - C.A. [4, vol. 4, pp. 5-6]).

This is a vision of paradise, of promise of a better life present and accessible to all. We see if first from outside, then crossing over from our world to that of Dostoevsky's book, from within. The fictional narrator, Gorianchikov, like the editor, begins with a vision of the world beyond. Having entered the fictional world we see it now through his eyes from onstage (from inside the prison of our vision):

"Our prison stood at the edge of the fortress, right at the ramparts. You would look through the chinks in the wall onto God's world to see if there was something out there. -And all you would see would be a scrap of sky and the tall earthen rampart, overgrown with weeds, with the sentries pacing back and forth, day and night, and the thought would come to you that years and years would go by, and you would come here in just the same way to look through the chinks in the wall and would see that same rampart, the same sentries and that same small scrap of sky, not the one over the prison, but a different one, one that was remote and free". 
“Острог наш стоял на краю крепости, у самого крепостного вала. Случалось, посмотришь сквозь щели забора на свет божий: не увидишь ли хоть что-нибудь? - и только увидишь, что краешек неба да высокий земляной вал, поросший бурьяном, а взад и вперед по валу, день и ночь, расхаживают часовые; и тут же подумаешь, что пройдут целые годы, а ты точно так же пойдешь смотреть сквозь щели забора и увидишь тот же вал, таких же часовых и тот же маленький краешек неба, не того неба, которое над острогом, а другого, далекого, вольного неба" [4, vol. 4, p. 9].

Like the ape in Vladimir Nabokov's postlude to Lolita, who sketches the bars of his cage (Nabokov tells of a newspaper article about an ape who, "after months of coaxing by a scientist, produced the first drawing ever charcoaled by an animal: this sketch showed the bars of the poor creature's cage" [13, p. 311] the prisoner sees a landscape of human structures of imprisonment and their agents - just one more layer of imprisonment. Only a sliver of that "distant, free sky" in "God's world" is visible. This perspective recalls Plato's cave, but here the observers see no shadows, and though painfully nearsighted, they face the world itself rather than its reflection.

Life, then (or though) is here. The fates of those who do manage to leave the prison suggest that ordinary human life is possible only inside. Outside is "that world" (тот свет; свет божий), which carries in Russian the figurative meaning of the world beyond ordinary human live, the afterworld. Those few who escape are brought back; those who serve their term make their way back as recidivists; hoboes and wanderers across the landscape of God's free world reenter the prison regularly at the first sign of inhospitable weather; those who are released disappear, or die. Such will be the fate, for example, of the eagle with the broken wing whom the prisoners free. Such, too, will be Gorianchikov's own fate: from the prison to temporary lodgings (Whatever else one might say about Gorianchikov's short subsequent life -his afterlife - in the Siberian town, it presents moral dangers: the wife-killer is surrounded by, and in fact entrusted with, at least six nubile teenage girls, five of whom "podava[li] prekrasnye nadezhdy" [4, vol. 4, p. 6], and thence into death.

Power originates outside. The agents of the law enforcement system come from outside; the doctors are free men and hold the power of life and death over the prisoners; protest, as eloquently demonstrated in the chapter entitled "Претензия", is pointless and impotent. All present are guilty, or at least judged so by the erratic and unreliable decisions of the human justice system. Of course these external forces -prison authorities, for example, or the court system - are more than what they appear to be. As everywhere in Dostoevsky's work, these mundane identities are masks for greater, invisible and morally loaded forces beyond. The convicts are all confined in prison because they are guilty (or judged guilty) of a sin. If our world, too, is a prison, then we, too are guilty - although in our case we can call our guilt original sin. In Dostoevsky's world-view, redemption comes only to those who have sinned. And if in the dead house the major brutally flogs the prisoners with sadistic pleasure, so, too, do free people suffer helplessly at the hands of a ruthless God, the deity that Ivan Karamazov, righteous, blind man that he is, accuses of injustice.

In Dostoevsky's symbolic world, it is not only coercive forces - wrathful sentries, agents of cruel justice - that are based "outside". Charity, too begins beyond the prison walls, where dwell people have devoted their lives to bringing mercy and comfort to the prisoners. The most memorable example of such a person is Nastasia Ivanovna, a widow who, though destitute herself, ministers to the prisoners in modest, but meaningful ways. Gorianchikov describes the charity of outsiders as "a completely selfless, saintly sympathy and compassion” (“сострадание и соболезнование... совер- 
шенно бескорыстное, святое" [4, vol. 4, p. 67]). Dostoevsky's genius chose the word "little angel" to denote another such messenger of divine mercy:

"A mother came toward me with her daughter, a girl of about ten years, as pretty as a little angel... She started to run after me... 'Here, unfortunate one, take a kopeck for Christ's sake'”.

“Навстречу мне прошли мать и дочь, девочка лет десяти, хорошенькая, как ангельчик... Та бросилась бежать за мной... «На, несчастный, возьми Христа ради копеечку»..." [4, vol. 4, p. 19].

Here the borders between Notes from the Dead House and the Epilogue of Crime and Punishment blur. For who is Sonya, patiently waiting for Raskolnikov outside his hospital window in Siberia, or ministering to his fellow prisoners as their "little mother", or suddenly appearing by his side on the Siberian river bank? Who is she, if not an angel of mercy, the Sophia of divine wisdom, the icon with her hand outstretched, the link to a transcendent reality?

"Suddenly Sonya appeared beside him. She had come up barely audibly and sat down next to him. It was still early; the morning cold had not yet lost its bite. She was wearing her shabby old pelisse and her green shawl. Her face still bore the signs of illness and was thinner and paler, hollowcheeked. The smile she gave him was joyful and welcoming, but she stretched her hand out to him timidly as usual".

“Вдруг подле него очутилась Соня. Она подошла едва слышно и села с ним рядом. Было еще очень рано, утренний холодок еще не смягчился. На ней был ее бедный, старый бурнус и зеленый платок. Лицо ее еще носило признаки болезни, похудело, побледнело, осунулось. Она приветливо и радостно улыбнулась ему, но, по обыкновению, робко протянула ему свою руку" [4, vol. 6, p. 421].

It is obvious that freedom is literally outside the prison, and of course it is the inhabitants of that world who provide the convicts with their rare tastes of that freedom - literally, in the case of the vodka that is smuggled in from outside. But if we are to interpret the prison as a metaphor for our own life, there is no comfort in just knowing that freedom exists somewhere "out there". Somehow, as "insiders", we will have to find it within. How does Dostoevsky communicate his message of hope? Within the stage set that he has created, the prison, Dostoevsky constructs settings that serve as symbolic spaces. These spaces serve as a setting for communal experience, where a mass of humanity gathers together. These spaces offer potential for escape, or conversely, they can serve to maintain the prisoners' state of unfreedom. The difference, as we will see, is one of vision. We will limit our focus here to three spaces: the bathhouse, the church, and the military barracks where the priest conducts the Christmas service and where the prisoners stage their theatrical performance.

The purpose of the bath, on the mundane level, is to clean up the prisoners for the Christmas holiday. In the most memorable line of the book, Gorianchikov enters the bathhouse and finds himself in an inferno: "When we opened the door into the bathhouse, I thought that we had entered Hell”. (“Когда мы растворили дверь в самую баню, я думал, что мы вошли в ад” [4, vol. 4, p. 98]). As critics have invariably noted, the vision of this hell is consciously and unmistakably Dantean (See [9, p. 37]). Here is the infernal heat, the hierarchically arranged rising circles of the benches, the impossible press of naked, filthy bodies filling every available space in a tiny, cramped room. What air is not occupied by human flesh is filled with steam and soot that blind the vision and clog the lungs. The men in the bath beat each other with birch switches; their shrieks and the clanking of the fetters 
and chains against the floor and walls creates a deafening din. Lest the reader miss the point, Gorianchikov concludes his description with another reminder:

"It occurred to me that if we would ever found ourselves all together in hell, then it would look very much like this place".

“Мне пришло на ум, что если все мы вместе будем когда-нибудь в пекле, то оно очень будет похоже на это место" [4, vol. 4, p. 99].

Individual distinctions among the prisoners are shed along with their clothing; the only thing they wear is the fetters that mark them all as unfree. Pressed together into a single human mass, they constitute one single, collective being, with three figures bearing its consciousness: Gorianchikov the observer, Isaiah Fomich, the king of hell; and Petrov, the chillingly amoral creature who serves as Gorianchikov's guide. Petrov is rumored to be the most fearsome of all prisoners, and he is (in the unlikely case that you didn't notice) the one who steals Gorianchikov's Bible. In the words of one of the prisoners:

"This was the most ruthless, the most fearless of all the prisoners... He was capable of anything; nothing would stop him if the impulse came over him. He would slaughter us, too, without remorse".

“Это самый решительный, самый бесстрашный из всех каторжных... Он на все способен; он ни перед чем не остановится, если ему придет каприз. Он и вас зарежет... и не раскается" [4, vol. 4, p. 84].

Petrov leads Gorianchikov into the burning core of this hell. They have to force themselves, with great difficulty, through the dense crowd to a choice spot in the bania, stepping over the heads of the convicts sitting on the floor. There is no place for Gorianchikov to sit. Petrov has to buy a space from another prisoner. Dostoevsky will repeat these telling details later, in the theater scene that will serve as an artistic response to this vision of hell. Before leaving the bathhouse, we should note that it is located not within the confines of the prison fortress, but outside, in the town.

Understandably, critical readers of the Notes tend to focus attention on the overtly religious imagery of Russian Orthodox ritual as a response to the hellish spectacle of the bathhouse. Still, Dostoevsky's most important messages are never communicated directly, and if a scene is to be judged by its effect, the religious rituals depicted here give grounds for skepticism. In the canonical interpretation, two Christian holidays - Christmas and Easter - give the prisoners respite from the dreary routine of life in the Dead House. Through communion they are given the opportunity to take their places, if only briefly, in the greater human community. The religious ceremonies aim to release the the prisoners -like other human beings - from the constricted, linear flow of ordinary - "small" time and bring them into contact with the "greater time" of eternity. Through the beauty of the orthodox ritual, the peasant-convict finds his own image and the potential for - if not the full realization of - salvation. In Jackson's reading, it is the outsider, the "deeply and consciously religious" nobleman who is morally cleansed by his prison experience and who will, through the act of authorship, "prophecy their ultimate redemption" [9, p. 106]. A closer look at the celebration of the religious holidays, however, may expose some vulnerability in any purely official, ritual-based spirituality.

The first holiday depicted in Notes from the Dead House is Christmas. Fresh and clean from their trip to the bathhouse, the prisoners are brought together in the prison's military barracks for the Christmas service. The military barrack is different from the others: "this was the only room in the prison that was not cluttered in the middle". ("это была единственная в остроге комната, не загроможденная посредине" [4, vol. 4, pp. 108-109]. The prisoners crowd into this space and the priest performs his rituals. Dostoevsky offers only a cursory description of the religious service it- 
self; the prisoners' attention (along with that of the reader and possibly even the priest himself) is focused primarily on the upcoming feast:

"Finally the priest arrived with the cross and holy water. After praying and chanting in front of the icon, he stood before the convicts, and all of them began to come forward and kiss the cross with sincere reverence. Then the priest proceeded through all the barracks and sprinkled them with holy water. In the kitchen he praised our prison bread..."

“Наконец пришел священник с крестом и святою водою. Помолвшись и пропев перед образом, он стал перед арестантами, и все с истинным благоговением стали подходить прикладываться к кресту. Затем священник обошел все казармы и окропил их святою водою. На кухне он похвалил наш острожный хлеб...” [4, vol. 4, p. 109].

The real attraction of the day turns out to be not the service itself, but the profane celebration that follows. After eating, the prisoners engage in unrestrained drunken revelry, profane singing, quarrels among themselves, and, as the alcohol begins to wear off, they fall into an oppressive state of shared misery:

"Misery, sorrow and a hazy stupor made their appearance amid the drunkenness and revelry. A prisoner who had been laughing an hour before had overdone it and was now sobbing... These poor people had wanted to have a good time, to celebrate the great holiday, and, Lord! What a miserable and oppressive day it had turned out to be for just about every one of them. It was as though each one of them had suffered a betrayal of some cherished hope".

“Грусть, тоска и чад тяжело проглядывали среди пьянства и гульбы. Смеявшийсь за час тому назад уже рыдал где-нибудь, напившись через край. <...> Весь этот бедный народ хотел повеселиться, провесть весело великий праздник - и, господи! какой тяжелый и грустный был этот день чуть не для каждого. Каждый проводил его, как будто обманувшись в какой-то надежде" [4, vol. 4, p. 111].

In the midst of this depressing scene a pair of drunken prisoners - a man and his demon - wander through, and the evening ends in the little demon's proto-Chekhovian refrain: "he's lying" (“врет!" [4, vol. 4, pp. 114-116]). Dostoevsky allows us to deduce the rest:

"But why describe all this intoxication? Finally the oppressive day comes to an end. The convicts slip heavily into sleep on their bunks. They talk and rave in their sleep even more than on other nights. The long awaited holiday has ended".

“Но что описывать этот чад! Наконец кончается этот удушливый день. Арестанты тяжело засыпают на нарах. Во сне они говорят и бредят еще больше, чем в другие ночи. <...> Давно ожидаемый праздник прошел" [4, vol. 4, p. 116].

Rather than elevating the prisoners' spiritual state, the Christmas service seems to have resulted in an intensification of the vice, sin and evil in the prison. It is a betrayal, a lie.

The other glimpse into the effects of the institution of Russian Orthodoxy comes at Easter, the traditionally celebrated time for renewal and rebirth. Gorianchikov's description of the advent of spring, the Lenten fast, and the prisoners' celebration of Easter comes after his return from the hellish hospital ward where he heard Akul'ka's husband's story. The prisoners are taken to the real church, in town (thus finding it paralleled symbolically with the bania, which is also situated outside the prison walls) [4, vol. 4, pp. 176-177]. Given Dostoevsky's theme of resurrection, one would expect the Easter service to serve as the artistic answer to the questions raised by the bathhouse scene. Still, the reader is left unsatisfied, and the questions remain. For the town church preserves the class divisions of society, and the prisoners are segregated from the congregation. Gorianchikov re- 
calls church services from his childhood, when the crowd of common churchgoers would part to allow dignitaries to make their way to the front. The humble people in the back would pray "in full consciousness of their lesser status (prinizhennosti)" [4, vol. 4, p. 177]; now he is one of them - a prisoner sharing a common fate with the others, - and here, too, they are divided. The crowd shrinks away from them: "Everyone recoiled from us, they even seemed to be afraid of us, they gave us alms each time" (“от нас все сторонились, нас все даже как будто боялись, нас каждый раз оделяли милостыней..." [4, vol. 4, p. 177]). The description of the church service is cursory and dry. The only hint at a spiritual effect comes at the end, when, hearing the words "Take me, even as a thief" (яко разбойника мя прийми), the prisonersnearly all collapsed onto the floor with a clanking of fetters, apparently taking the words literally as referring to them personally" “почти все повалились в землю, звуча кандалами, кажется приняв эти слова буквально на свой счет" [4, vol. 4, p. 177]). The promise of transfiguration is undermined by the lethal Dostoevskian qualifier "apparently", and betrayed by the profane celebration that follows the service. What we witness is anything but spiritual renewal: the prisoners gorge themselves on an unusually heavy meal, and descend into predictable drunkenness and boredom. This effect is directly compared to that of the Christmas holidays:

"Now Holy Week arrived. The administration issued us each one egg and one piece of wheat bread. Again the prison was inundated with alms. Again the priest came with his cross, again greasy cabbage soup, again drunkenness and staggering around - all exactly the same as at Christmas, with the difference that now it was possible to stroll about outside in the prison yard and bask in the sunshine. It was somehow brighter, more open than during the winter, but somehow sadder. The long, endless summer day became somehow particularly unbearable during the holidays. During regular workdays at least our labor made the time go faster".

“Но вот пришла и святая. От начальства вышло нам по одному яйцу и по ломтю пшеничного сдобного хлеба. Из города опять завалили острог подаянием. Опять посещение с крестом священника, опять жирные щи, опять пьянство и шатанье - все точь-в-точь как и на рождестве, с тою разницею, что теперь можно было гулять на дворе острога и греться на солнышке. Было как-то светлее, просторнее, чем зимой, но как-то тоскливее. Длинный, бесконечный летний день становился как-то особенно невыносимым на праздниках. В будни, по крайней мере сокращался день работою" [4, vol. 4, p. 177].

Phrases that undermine the message of spiritual renewal are highlighted. If the prisoners are to achieve freedom and peace, it will not come through Russian Orthodox ritual.

Physical passage beyond the gates of the prison does not liberate the prisoners; outside they find only more imprisonment (forced labor) and temptation: money, illicit vodka, wretched prostitutes, impotent church services, and the filthy hell of the bathhouse. The truly meaningful spiritual transformations in Notes from the Dead House come not from the church institution and its rituals, nor from any mere political or physical liberation, but from deep within: inside the individual prisoners themselves and within their community. Prisoners seek escape through dreams, drunkenness, spending sprees, and prayers, but the one occasion when they move beyond these private solutions to attain true community comes with the theatrical performance. If, as Robert Louis Jackson argues, the grim tale of the murder of Akulka that Gorianchikov overhears in the prison hospital is the "deepest level of Dostoevsky's hell" [9, p. 71], then the theatrical performance, which follows Akul- 
ka's story in the narration, provides a glimpse of redemption. What is this, if not a deeply sacramental - but yet profane - mimicry of the trappings of Russian orthodox ritual?

Jackson's masterful interpretation of "Akulka's Husband" reveals the murdered woman to be an icon, "a pure embodiment of Russian spirituality" [9, p. 114] that remains pure in a world that seems utterly dominated by sin, deception, and cruelty. Akulka herself is pure, but no one recognizes this because a vindictive suitor has slandered her. True to the Dostoevskian pattern of holiness, she remains passive and non-resistant to evil, but her image gives a promise of redemption. Like all of Dostoevsky's most powerful writing, the message comes deeply embedded in layers of narrative (a story within a story - that golden kernel concealed by ugly husk). Jackson suggests that although the poverty, brutality, ignorance, and drunkenness of live in Akulka's village, "the rituals of the church are observed, and the icon - the model, the 'image of God'- is before everybody's eyes" [9, p. 103]. In my reading, the iconic image is in fact opposed to the rituals of official Orthodoxy. This view of redemption seemingly absent, but available to all who have eyes to see, will be the message of the prisoners' theatrical presentation.

The transfigurative moment comes not at the end of the book, as a plot-based reading would have it. Rather we find it at the very center of the Dead House (The literal center: Chapter 11 of a twenty-chapter book. In the PSS edition, in which Notes takes up 232 pages, the Theater chapter begins on p. 116) - at the grimmest possible time - in the dark depth of winter, in the heart of the prison, in the souls of the prisoners. As always in Dostoevsky's most important moments, the kernel of truth is concealed in layers of artistic disguise: theatrical costumes, a stage performance, and the narrative layers of the Notes as a whole. Here, as elsewhere (notably, for example, in the Luzhin slander-scene in Crime and Punishment (see Chapter VI below) Dostoevsky gives the reader a dense crowd of fallen humanity, ready for a collective redemption. On the third day of the Christmas holiday, as they recover from their hangovers, the prisoners stage a theatrical performance, with no external help or interference. Dostoevsky deploys his characeristic situation rhyme, utilizing significant details from the two other previous (and related) holiday crowd scenes (the bania and the barracks Christmas service) to establish a direct contrast, and thereby, artistic response, to them. It takes place in the same military barracks where the priest had conducted the Christmas service. The birch switches the prisoners use to whip each other in the bath are recalled here in the sturdy logs (поленья - 122) on which the prisoners stand to watch the performance. The barracks interior is fifteen paces long and ten paces wide (144 square paces), thus approximately the same size as the bath (which is twelve paces square: 150 square paces). In an inverted parallel to the prisoners' visit to the town church, the slightly larger barracks accommodates additional "free" guests from outside the prison. Though here the external door opens out onto the freezing cold air of winter, it is hot inside and the crowding recalls that of the bathhouse:

"The crowding in the front half of the barracks was unnatural and equaled the oppressive crush of people that I had seen not so long ago in the bath".

“Теснота в первой половине казармы была неестественная и равнялась, может быть, тесноте и давке, которую я недавно еще видел в бане" [4, vol. 4, p. 121].

The same cast of characters is present for the performance, and here, too, Petrov serves as Gorianchikov's guide: But what a difference! There, he and Gorianchikov had had to push their way through to their place; here, the crowd voluntarily parts to let them through: "Petrov and I were immediately allowed to pass through to the front, almost all the way to the benches where the view was much better than in the back rows”. ("Нас, меня и Петрова, тотчас же пропустили вперед, 
почти к самым скамейкам, где было гораздо виднее, чем в задних рядах" [4, vol. 4, p. 121]). There, the prisoners whip one another; here, they lean on each other ("leaning both hands on the shoulders of the person standing in front of them" ("обеими руками упирался в плеча впереди стоящего" [4, vol. 4, p. 122]). There they shriek and wail; here they are reverently silent and patient: "What a strange glow of childish joy, of young, pure pleasure on these faces!" “Что за странный отблеск детской радости, милого, чистого удовольствия сиял... в этих взглядах" [4, vol. 4, p. 122]). There Gorianchikov was held in scorn; here the prisoners make way for him. The focal point of the bath was Isaiah Fomich, the Jew, reveling on the topmost shelf, where it is hottest, shrieking, insatiable in his need for steam, heat, and whipping. Here, the all eyes are directed at the curtain:

"I was struck most of all by the curtain. It was ten paces long and extended across the entire barrack. The curtain was such a luxury that it was truly deserving of wonderment. Furthermore, it had been decorated in oil paints depicting a country scene with arbors, ponds, and stars. It was made of canvas, old and new depending on what the donors had been able to spare. It was made of old convict footcloths and sheets sewn together haphazardly into one large panel and, finally, part of it, for which there had not been sufficient cloth was made out of plain paper, which had also been begged, pageby page, from various prison offices and bureaus. Our prison artists, among whom Briullov-A-v was particularly distinguished, had taken considerable care to decorate and paint it. The effect was astonishing. Even the most gloomy and finicky prisoners rejoiced at such splendor, and when it came to the performance, all of them turned out to be just as childishly enthusiastic as the most passionate and impatient of the prisoners".

“Прежде всего меня поразила занавесь. Она тянулась шагов на десять поперек всей казармы. Занавесь была такою роскошью, что действительно было чему подивиться. Кроме того, она была расписана масляной краской: изображались деревья, беседки, пруды и звезды. Составилась она из холста, старого и нового, кто сколько дал и пожертвовал, из старых арестантских онучек и рубах, кое-как сшитых в одно большое полотнище, и, наконец, часть ее, на которую не хватило холста, была просто из бумаги, тоже выпрошенной по листочку в разных канцеляриях и приказах. Наши же маляры, между которыми отличался и Брюллов - A-v (even the worst sinner of all, the traitorous A-v), позаботились раскрасить и расписать ее. Эффект был удивительный. Такая роскошь радовала даже самых угрюмых и самых щепетильных арестантов, которые, как дошло до представления, оказались все без исключения такими же детьми, как и самые горячие из них и нетерпеливые" [4, vol. 4, pp. 120-121].

The curtain, portraying a pastoral, natural landscape, serves as a homemade - secular - iconostasis. It works a miraculous transformation in the impossibly dense crowd of prisoners standing in the back of the room behind the seated spectators from the free world. They stand hatless, silent, expectant. From hung-over, dangerous criminals they have become innocent children gazing blissfully, in wonder (“с блаженством в лице... отблеск детской радости... наивное" [4, vol. 4, p 122]), at the marvelous curtain. Looking back at them from his place of honor at the front of the room (from near the stage), through the dim light provided by a few short tallow candles (also reminiscent of church, of course), Gorianchikov sees their true inner goodness for the first time:

"All it takes is to remove the external, superficial crust and look carefully at the kernel inside, closely, without prejudice - and you will see in the people things the likes of which you could never imagine, Our wise men have very little to teach the people. In fact, I can assert with confidence, on the contrary: they themselves ought to learn from them". 
“Стоит только снять наружную, наносную кору и посмотреть на самое зерно повнимательнее, поближе, без предрассудков - и иной увидит в народе такие вещи, о которых и не предугадывал. Немногому могут научить народ мудрецы наши” [4, vol. 4, p. 121-122].

Instead of the strictly choral music of the Russian orthodox church, the prisoners play secular instruments: fiddles, guitars, home-made balalaikas, and a tambourine. The performance itself is a secular burlesque, featuring adultery and devils. The whole performance: the setting, the characters, the plays themselves, the music - serves as a travesty of Russian orthodox ritual. And yet, it works a true transfiguration among the prisoners. The spectators go home happy, satisfied, and even innocent:

"We all dispersed after the performance joyful, satisfied, praising the actors and thanking the sergeant. There was no hint of any brawling. Everyone was somehow unusually satisfied, even what might be called happy, and they were falling asleep not in the usual way, but practically with their spirits at peace, - and from what, might it seem? And nevertheless, it was not just a dream of my imagination. It was true and real. These poor people had been permitted to live in their own way for just a short time, to enjoy themselves like human beings, to live, if only for an hour not as though they were in prison, and a person changes morally, if only for just a few moments".

“Наши все расходятся веселые, довольные, хвалят актеров, благодарят унтер-офицера. Ссор не слышно. Все как-то непривычно довольны, даже как будто счастливы, и засыпают не по-всегдашнему, а почти с спокойным духом, - а с чего бы, кажется? А между тем это не мечта моего воображения. Это правда, истина. Только немного позволили этим бедным людям пожить по-своему, повеселиться по-людски, прожить хоть час не по-острожному - и человек нравственно меняется, хотя бы то было на несколько только минут..." [4, vol. 4, p. 129-130].

In a direct response to the hell of Akulka, which emerges from a dreamlike state (Gorianchikov hears it while half-asleep), Dostoevsky's redemptive vision leads into dreams. In sleep the prisoners are innocent children of God. Their souls all find expression in the "calm childish face" ("спокойное детское лицо" [4, vol. 4, p. 130]) of the sleeping Alei (himself imprisoned for the sins of his brothers) (The paradox of a Muslim Christ child as the image of grace deserves a more focused treatment than it can be given here. (See [15]). As Gorianchikov looks at them, the truth of the prison barracks mixes inextricably with the greater truth of revelation:

"I look at their poor faces, at their poor beds, at this entire, impenetrable hunger and wretchedness, - I look closely, and it is as though I want to assure myself that this is all not just the continuation of a monstrous dream, but the actual truth. But it is the truth: someone's groan is heard; someone flings out his arm with a clanging of fetters. Another shudders in his sleep and starts talking, and the old man on the stove prays for all "Orthodox Christians", and I can hear his rhythmical, quiet, drawn-out "Lord, Jesus Christ, have mercy on us!"

- And after all I am not here for ever, just for a few years", - I think and lay my head down on the pillow".

“Я смотрю на их бедные лица, на их бедные постели, на всю эту непроходимую голь и нищету, - всматриваюсь - и точно мне хочется увериться, что все это не продолжение безобразного сна, а действительная правда. Но это правда: вот слышится чей-то стон; кто-то тяжело откинул руку и брякнул цепями. Другой вздрогнул во сне и начал говорить, а дедушка на печи молится за всех “православных христиан”, и слышно его мерное, тихое, протяжное “Господи Иисусе Христе, помилуй нас!..”

- Не навсегда же я здесь, а только ведь на несколько лет! - думаю я и склоняю опять голову на подушку" [4, vol. 4, p. 130]. 
If we put ourselves into the place of the prisoners, and view the prison as our own material surroundings (nay, our bodies themselves), we will find this message applicable not only to prisoners, or nineteenth-century Russians, or any other group, but directly to ourselves. The message, then, of reconciliation and salvation is found not somewhere else, in that "god's world" that we all seek without finding, outside ourselves, but right here inside the prison of our own vision.

\section{REFERENCES}

1. Bakhtin M. Rabelais and His World, Tr. Helene Iswolsky. Cambridge, MA.: MIT Press, 1968.

2. Bakhtin M. Forms of Time and of the Chronotope in the Novel: Notes Toward a Historical Poetics. The Dialogic Imagination: Four Essays. Ed. Michael Holquist, tr. Caryl Emerson and Michael Holquist. Austin: The University of Texas Press, 1981. Pp. 84-258.

3. Bakhtin M. Problems of Dostoevsky's Poetics, edited and translated by Caryl Emerson. Minneapolis: University of Minnesota Press, 1984.

4. Достоевский Ф. М. Полное собрание сочинений: в 30 т. Л.: Наука, 1972-1990.

5. Emerson Caryl and Gary Saul Morson: Mikhail Bakhtin. Creation of a Prosaics. Stanford, CA: Stanford UP, 1990.

6. Finke M. The Hero's Descent to the Underworld in Chekhov // Russian Review. 1994. Vol. 3. No. 1. Pp. 67-80.

7. Flath C. A. Fear of Faith: The Hidden Religious Message of Notes from Underground // Slavic and East European Journal. 1993. Vol. 4. Pp. 510-529.

8. Frank J. Dostoevsky: The Years of Ordeal 1850-1859. Princeton: Princeton UP, 1983.

9. Jackson R. L. The Art of Dostoevsky: Deliriums and Nocturnes. Princeton: Princeton University Press, 1981.

10. Kermode F. The Genesis of Secrecy: On the Interpretation of Narrative. Cambridge, MA: Harvard University Press, 1979.

11. Lahusen T. De la Tautologie: Reflexions sur les Notes d'un Souterrain de F. M. Dostoevskij (Contribution a une Linguistique du Texte litteraire) // Russian Literature. 1989. Vol. 25. No. 2. Pp. 141-198.

12. Morson G. S. The Boundaries of Genre: Dostoevsky's Diary of a Writer and the Traditions of Literary Utopia. Evanston: Northwestern University Press, 1981.

13. Nabokov V. The Annotated Lolita. New York: Vintage, 1955.

14. Tolstoi L. Chto takoe iskusstvo // Tolstoi L. Polnoe sobranie sochinenii. Moscow-Leningrad: Khudozhestvennaia literatura.

15. Rosenshield G. Islam and the Russian Orthodox Ideal // Notes from the "House of the Dead", XII Symposium of the International Dostoevsky Society. Geneva, 1-5 September, 2004. 
DOI: 10.15643/libartrus-2014.5.4

\title{
Символика пространства в «Записках из мертвого дома»
}

\author{
(C) К. Аполлонио \\ Duke University \\ 500 North Duke St., 27701 Durham, NC, USA. \\ Тел.: +1 (919) 6603140 . \\ Email: flath@duke.edu
}

В статье предлагается анализ парадоксальной символики пространства в трех сценах «Записок из Мертвого дома». Несмотря на то, что свободу в прямом смысле слова можно приобрести только вне пределов тюрьмы, и на то, что в общественном мире она доступна только немногим, в косвенном, более глубоком смысле свобода доступна всем, и она испытывается внутри стен тюрьмы, внутри каждого человека. Сцена «Баня», как неоднократно отмечено учеными, дает картину ада. Но баня, как и церковь, в которую ходят заключенные на праздник Пасхи, находится в городе, не в тюрьме. Исследуются параллели между этими сценами и сценой театра, кульминацией первой части романа. Представление проходит в самой казарме, где живут заключенные. Занавес можно рассмотреть, как иконостас, а спектакль как церковную службу. После театрального представления, обитатели острога испытывают глубокое чувство спокойствия и блаженства, которых они не испытывают ни в каком другом месте: «Все как-то непривычно довольны, даже как будто счастливы, и засыпают не по-всегдашнему, а почти с спокойным духом». Таким образом, в «Записках из мертвого дома» передается новое видение «свободы» в самом центре тюрьмы. В статье цитируются труды Бахтина, Эмерсон, Джэксона и других исследователей.

Ключевые слова: Ф. М. Достоевский, Записки из Мертвого дома, хронотоп, театр, иконостас, церковная служба, свобода.

Просьба ссылаться на эту работу как: Apollonio C. Notes From the Dead House: An Exercise in Spatial Reading, or Three Crowd Scenes // Liberal Arts in Russia. 2014. Vol. 3. No. 5. Pp. 354-368. 